\title{
Effects of whey or maltodextrin addition during production on physical quality of white cheese powder during storage
}

\author{
Zafer Erbay* and Nurcan Kocat $^{1}$ \\ *Department of Food Engineering, Faculty of Engineering and Natural Sciences, Adana Science and Technology University, 01180 Adana, Turkey \\ †Department of Food Engineering, Faculty of Engineering, Ege University, 35100 Izmir, Turkey
}

\begin{abstract}
There is an increasing demand for cheese as a food ingredient, especially as a flavoring agent. One of the most important cheese flavoring agents is cheese powder. To obtain an intense cheese flavor, ripened cheese is used as a raw material in cheese powder but this increases production costs. Moreover, use of natural cheese decreases the physical quality of powder because of its high fat content. In this study, we evaluated opportunities to use whey or maltodextrin for improving the physical quality of powders in production of white cheese powder. We produced cheese powders with 3 different formulations - control (CON), whey-added (WACP), and maltodextrin-added (MACP) - and determined the effects of formulation on cheese powder quality. Physical quality parameters such as color, densities, reconstitution properties, free fat content, particle morphology, and sensory characteristics were investigated. The different cheese powders were stored for $12 \mathrm{mo}$ at $20^{\circ} \mathrm{C}$ and we evaluated the effect of storage on powder quality. Addition of maltodextrin to cheese powder formulations significantly improved their physical quality. The densities and reconstitution properties of cheese powder were increased and free fat content was decreased by use of maltodextrin. The MACP particles were spherical with a uniform distribution and larger particle sizes, whereas CON and WACP particles were wrinkled, irregularly shaped with deep surface dents, and variable in size. Although caking was observed in scanning electron micrographs after 12 mo of storage, it was not detected by sensory panelists. The color of cheese powders changed very slowly during storage but browning was detected. The results of this study show that it is possible to use maltodextrin or whey in production of white cheese powder to reduce production costs and improve the physical quality of powders.
\end{abstract}

Received April 29, 2015

Accepted August 14, 2015.

${ }^{1}$ Corresponding author: nurcan.koca@ege.edu.tr
Key words: cheese powder, white cheese, whey, maltodextrin, storage

\section{INTRODUCTION}

Recently, there has been an increasing demand for cheese as a food ingredient, especially as a flavoring agent. For flavoring, the best material is ripened cheese and traditionally cheese has been added to food products in a spray-dried powder form to enhance flavor, appearance, and texture. In this context, the most important dehydrated cheese product is cheese powder. The best way to obtain a quality product with intense cheese flavor is to use ripened cheese as the raw material. However, the high cost of ripened cheese restricts its use in cheese powder manufacture. Moreover, the use of natural cheese has a detrimental effect on some physical properties, such as reconstitution of powders, because of its high fat content (West, 2007; Guinee, 2011).

The quality of cheese powders depends on many parameters. Physical features of powders are very important, especially in industrial applications. The composition of cheese powder provides useful information about not only the main physical and storage properties, but also the structure and morphological features of powder particles (Kim et al., 2002; Fitzpatrick et al., 2004; Thomas et al., 2004; Barbosa-Canovas et al., 2005; Vignolles et al., 2007; Paterson et al., 2007). Additionally, free fat content in powders directly influences the reconstitution and storage features of powders (Kelly et al., 2002; Kim et al., 2002, 2009; Vignolles et al., 2007, 2009; Park et al., 2014). Moreover, physical properties of powders such as color, which can indicate defects during processing and storage, and densities, which are used to determine storage, processing, packaging, and distribution conditions, are critical properties (Barbosa-Canovas et al., 2005; Schuck, 2011). Furthermore, most food additives that are prepared in powder form need to be hydrated before using. Therefore, interfacial properties, water interactions, and dissolution of dairy powders are important factors in food development 
and formulation (Thomas et al., 2004; Schuck, 2011; Richard et al., 2013). The process of reconstituting dairy powders with water depends on a combination of several properties, such as wettability, sinkability, dispersibility, and solubility (Freudig et al., 1999; Schuck, 2011). In addition to all these, sensory characteristics are an important property to ensure customer satisfaction (Koca et al., 2015).

In previous studies, we reported the energetic performance and improvement opportunities in cheese powder production and cost formation mechanisms in production (Erbay and Koca, 2012a,b; Erbay and Koca, 2014). We determined the effects of spray-drying process conditions and optimized the spray-drying process (Erbay et al., 2015; Koca et al., 2015). These studies showed that although powders with strong cheese flavors can be produced, their physical properties are not good enough to be used by industry. Further, the simplest way to decrease raw material costs is to use additives such as carriers or fillers to substitute for ripened natural cheeses (Erbay and Koca, 2012a,b, 2014; Erbay et al., 2015; Koca et al., 2015). The use of carriers or fillers may also improve the physical properties, especially the reconstitution properties of powders. In the food industry, one of the most commonly used materials as a carrier or filler is maltodextrin. Maltodextrins are hydrolysis products of starches and they are a mixture of saccharides with a broad molecular weight distribution between polysaccharides and oligosaccharides. Maltodextrins are known to improve particle size, bulk density, hygroscopicity, solubility, and caking properties (Chronakis, 1998; Danviriyakul et al., 2002; Papadakis et al., 2006; Goula and Adamopoulos, 2008; Gianfrancesco et al., 2010). Another material frequently used in powder formulations is whey. Whey is a very important byproduct of dairy industry with a high functional protein content. It is widely used in powder formulations to improve the physical quality of powders such as particle properties, reconstitution abilities, and flowability (Thomas et al., 2004; Kelly, 2006; Schuck et al., 2007; Hoppe et al., 2008; Charve and Reineccius, 2009; Dissanayake et al., 2012). Although whey is generally used in powder form, especially in industrial applications, use of fluid whey showed promising results for some meat products (Yetim et al., 2001, 2006; Das and Sharma, 2009; Terra et al., 2009). The use of fluid whey may be a good option especially if the production plants of cheese powder and cheese are close. In cheese powder production, fluid whey may be used to substitute for both cheese solids and water. Moreover, the cost of fluid whey is lower than that of whey powder.

Few studies have focused on cheese powder in the scientific literature; to our knowledge, the effects of product formulation on cheese powder quality have not been investigated. The primary motivation behind this study was to investigate opportunities for addition of whey or maltodextrin to the cheese powder formulation to increase the physical quality of powders while reducing raw material costs. Moreover, variations in product quality parameters during storage were studied.

\section{MATERIALS AND METHODS}

\section{Materials}

White cheese ripened for 7 mo was supplied by Sütaş Dairy Company (Bursa, Turkey). White cheese blocks were ground into small pieces, transferred to air- and water-tight durable polypropylene plastic containers, stored at $2^{\circ} \mathrm{C}$, and processed within $48 \mathrm{~h}$. Whey was obtained from Kashar cheese production in Pınar Dairy Company (İzmir, Turkey). It was pasteurized, cooled to refrigeration temperature, and used within $3 \mathrm{~d}$ to avoid the increase of acidity. Although whey is typically used in powder form, we used fluid whey to substitute both cheese DM and water. Maltodextrin (dextrose equivalent value of 20) was purchased from Qimhuangdao Starch Co. (Hebei, China). The composition of white cheese and whey used in the study is reported in Table 1. The moisture content (mean $\pm \mathrm{SD}$ ) of maltodextrin used in production of cheese powders was $5.45 \% \pm 0.14$.

\section{Production Procedure}

Before spray drying, cheese emulsions were produced with $25 \%$ DM. In this study, cheese emulsions were prepared with 3 different formulations: cheese emulsion (CE) to produce control cheese powder $(\mathbf{C O N})$, wheyadded cheese emulsion (WACE) to produce whey-added cheese powder (WACP), and maltodextrin-added cheese emulsion (MACE) to produce maltodextrinadded cheese powder (MACP).

Cheese emulsion (the control sample) was composed of ground white cheese, water, and Joha emulsifying salts (Kipa Chemical Company, Istanbul, Turkey) at $3 \%$ (based on cheese weight). The ingredients were heated by adding hot water and sheared in a blender (model LB10S, Waring, Torrington, CT) at 6,000 rpm for $1 \mathrm{~min}$. Subsequently, the slurry was heated in a water bath to $80^{\circ} \mathrm{C}$ and sheared again at $6,000 \mathrm{rpm}$ for $10 \mathrm{~min}$. The slurry was fed to the spray dryer at $45^{\circ} \mathrm{C}$.

Whey was used in place of water in the production of WACE, whereas maltodextrin was added directly to replace $30 \%$ of cheese DM to produce MACE. To keep the DM content of WACE constant, white cheese use was reduced by approximately $13 \%$. 
After preparation of cheese emulsions, they were fed to a pilot-scale spray dryer (Mobile Minor NiroAtomizer, GEA Niro, Soeborg, Denmark). The schematic illustration of the spray-drying system and the equipment used in drying were presented in a previous study (Erbay and Koca, 2012b). The drying conditions were selected according to a previous optimization study focused on spray drying of white cheese (Erbay et al., 2015). In that study, optimum conditions were determined to be $174^{\circ} \mathrm{C}$ for inlet drying temperature, $354 \mathrm{kPa}$ for atomization pressure, and $68^{\circ} \mathrm{C}$ for outlet drying temperature. Cheese powders with each formulation were produced twice.

The cheese powder samples were packaged in polyethylene terephthalate/aluminum/low-density polyethylene (PET/Al/LDPE), and stored for $12 \mathrm{mo}$ at $20^{\circ} \mathrm{C}$ and 40 to $50 \%$ relative humidity. Powders were analyzed every 3 mo during storage.

\section{Composition}

Moisture, fat, and protein contents of cheese, emulsion, and powder samples were determined by gravimetric (IDF, 1982), Gerber (IDF, 1981), and Kjeldahl (AOAC International, 2000a) methods, respectively. Ash contents of powders were determined by the gravimetric method (AOAC International, 2000b), whereas salt contents were analyzed by the Mohr method (IDF, 1988). Titratable acidity was expressed as percentage lactic acid (AOAC International, 2000c), and $\mathrm{pH}$ was measured with a $\mathrm{pH}$ meter. Compositional analyses were done in duplicate.

\section{Color Evaluation}

Using a Hunter ColorFlex colorimeter (Hunter Associates Laboratory, Reston, VA), cheese powder color was measured in terms of $\boldsymbol{L}$ (lightness to darkness), $\boldsymbol{a}$ (redness to greenness), and $\boldsymbol{b}$ (yellowness to blueness). A quartz glass containing the cheese powder was placed above the light source and covered with an opaque cover; then, $L, a$, and $b$ values were recorded. The analyses were done in quadruplicate. Color differences $(\boldsymbol{\Delta} \boldsymbol{E})$ with $\mathrm{CE}$ and white cheese as reference, chroma (color intensity), and browning index (BI) values were calculated (Askari et al., 2008) as follows:

$$
\begin{gathered}
\Delta E=\sqrt{\left(L_{0}-L\right)^{2}+\left(a_{0}-a\right)^{2}+\left(b_{0}-b\right)^{2}}, \\
\text { Chroma }=\sqrt{a^{2}+b^{2}}, \text { and }
\end{gathered}
$$




$$
\mathrm{BI}=\frac{100 \times\left[\frac{(a+1.75 \times L)}{(5.645 \times L+a-3.012 \times b)}\right]}{0.17} .
$$

\section{Powder Density Determination}

Bulk, tapped, and particle densities of white cheese powders were measured. Bulk density was measured by pouring white cheese powder to the $100-\mathrm{mL}$ mark of a tared graduated cylinder and recording the weight (Jinapong et al., 2008). The measuring cylinder was tapped 200 times and the volume was recorded to calculate the tapped density (Jinapong et al., 2008). Particle density was measured by the fluid displacement method in a $100-\mathrm{mL}$ volume liquid pyknometer and with petroleum ether (Svarovsky, 1987; BarbosaCanovas et al., 2005). All densities were expressed in kilograms per meter cubed and analyses were made in duplicate.

\section{Powder Reconstitution}

Three properties of white cheese powder (wettability, dispersibility, solubility) were investigated to evaluate overall reconstitution abilities. Wettability was determined by the methods described in GEA Niro (2005a) and Jinapong et al. (2008), with some modifications. The aim was to investigate changes during storage and the modifications were made to determine the variations more accurately. As the fat contents of powders were in the range of 35 to $49 \%$, the times required to wet the powders were very long. Therefore, the amount of powder used in the analysis was determined according to the least-wettable powder sample. In this study, the amounts of distilled water and powder were $100 \mathrm{~mL}$ (in a $250-\mathrm{mL}$ beaker) and $0.075 \mathrm{~g}$, respectively. The temperature of distilled water was $35 \pm 1^{\circ} \mathrm{C}$ and the samples were poured onto the water from a height of 10 $\mathrm{cm}$. Wettability analyses were made in quintuplicate. Dispersibility was determined by the method described by Jinapong et al. (2008), except that the sieve had a diameter of $500 \mu \mathrm{m}$. Dissolubility was determined by the solubility index or Haenni method (Hawthorne, 1944). Dispersibility measurements were made in quadruplicates, and dissolubility was measured in triplicates.

\section{Free Fat Content}

The free fat content of dairy powders is commonly quantified by the solvent extraction method (Vignolles et al., 2007). In this study, the modified solvent extraction method described in GEA Niro (2005b) was used.
Analysis was made in quadruplicate and the results were expressed as the percentage of free fat content.

\section{Scanning Electron Microscopy}

Cheese powder samples were attached to the double-sided adhesive carbon tabs mounted on scanning electron microscopy stubs, coated with gold by using a sputter coater (Polaron SC7610, Quorum Technologies Ltd., Kent, UK), and examined under a Philips scanning electron microscope (Philips XL30, Eindhoven, the Netherlands) equipped with a Everhart-Thornley detector (Koca et al., 2015).

\section{Water Activity}

Water activity values of white cheese powder samples were measured with a water activity measurement probe (Testo, Freiburg, Germany).

\section{Glass Transition Temperature}

Differential scanning calorimetry (DSC; PerkinElmer DSC 8000, with $\mathrm{N}_{2}$ cooling, Waltham, MA) was used to measure glass transition temperature of the powder samples. Samples were prepared in preweighed DSC aluminium pans and the pans were then hermetically sealed. Duplicate samples of each material were analyzed. An empty pan was used as a reference. The samples were heated from $-70^{\circ} \mathrm{C}$ to $250^{\circ} \mathrm{C}$ at $5^{\circ} \mathrm{C} / \mathrm{min}$, then cooled at $10^{\circ} \mathrm{C} / \mathrm{min}$ to $-70^{\circ} \mathrm{C}$, and the second heating scan at $5^{\circ} \mathrm{C} / \mathrm{min}$ to $200^{\circ} \mathrm{C}$ was run. The data obtained from second heating were recorded (Jouppila and Roos, 1994; Fitzpatrick et al., 2007).

\section{Sensory Evaluation}

The sensory properties of white cheese powder samples were determined using 10 trained panelists. Caking degree, flowability, and color (browning degree) were determined. A unipolar scale ranging from 1 (none/ absent) to 9 (highest intensity) was used for each sensory property. To evaluate the sensorial properties and defects that can occur in cheese powders, cheese powder samples were cooked at different temperatures and times. All panelists evaluated these cheese powder samples (Koca et al., 2015).

\section{Statistical Analysis}

Statistical analyses were performed using SPSS software (ver. 13.0 for Windows, SPSS Inc., Chicago, IL). 
Table 2. Color characteristics (mean $\pm \mathrm{SD}$ ) of white cheese, emulsions prepared during production, and powders with different formulations

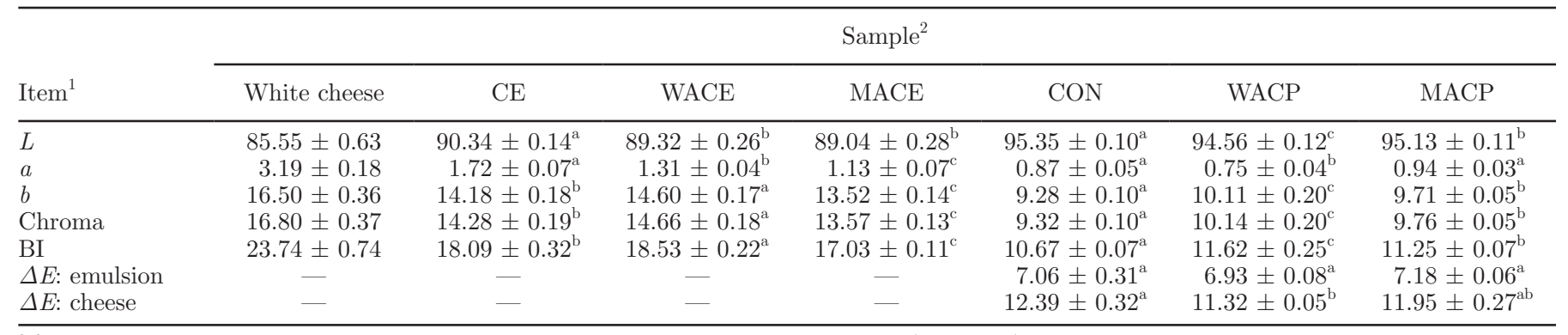

${ }^{\mathrm{a}-\mathrm{c}}$ Means within a row with different superscripts differ for emulsions and powders $(P<0.05)$.

${ }^{1} L=$ lightness-darkness; $a=$ red-green color; $b=$ yellow-blue color; $\mathrm{BI}=$ browning index; $\Delta E$ : emulsion $=$ color difference with cheese emulsion as reference; $\Delta E$ : cheese $=$ color difference with white cheese as reference.

${ }^{2} \mathrm{CE}=$ cheese emulsion, WACE $=$ whey-added cheese emulsion, MACE = maltodextrin-added cheese emulsion, $\mathrm{CON}=$ control cheese powder, WACP $=$ whey-added cheese powder, MACP $=$ maltodextrin-added cheese powder .

Data were analyzed by ANOVA and Duncan post hoc test. Statistical significance was set at $P<0.05$.

\section{RESULTS AND DISCUSSION}

Color features of white cheese used in powder production and cheese emulsions prepared with different formulations are shown in Table 2. The emulsifying process resulted in a whiter color. The $L$ value increased during processing, whereas $a$ and $b$ values decreased. Fat globule size influenced the lightness of color. The smaller the fat globule size, the greater the lightness of dispersion, which in turn whitens the color of the product. Similar results were obtained during the processing of a traditional Brazilian processed cheese spread called Requeijao cremoso (Cunha and Viotto, 2010). The lowest $L, a$, and $b$ values were obtained from MACE samples. We measured the highest $L$ and $a$ values in $\mathrm{CE}$, whereas the highest $b$ values were obtained from WACE. We observed that $b$ values were the dominant parameter affecting BI and chroma values (Table 2).

\section{Effects of Formulation on Powder Properties}

The compositions of the cheese powders produced with different formulations are listed in Table 1. All powders had moisture contents lower than 3\%. The lowest contents of protein, fat, ash, and salt, and titratable acidity values were obtained in MACP, followed by WACP.

Although measured color values were similar, we detected statistically significant differences between samples $(P<0.05)$. We obtained the lowest $b$ and the highest $L$ values from CON, whereas the lowest $a$ values were found in WACP (Table 2). In accordance with the results of primary color values, we calculated the lowest chroma and $\mathrm{BI}$ values for $\mathrm{CON}$, followed by
MACP. When we used cheese emulsion as the reference color, it was not possible to determine a difference between the powders, indicating that powder formulation did not significantly influence color during spray drying $(P>0.05)$. However, we determined that WACP most resembled white cheese due to its color features, indicating that the processing of cheese caused statistically significant variations in color with different formulations $(P<0.05)$.

Table 3 illustrates that the physical and physicochemical properties of cheese powders were significantly altered by formulation $(P<0.05)$. The MACP samples had the highest bulk, tapped, and particle densities. Moreover, MACP samples were the most wettable, dispersible, and soluble samples with the lowest free fat contents, primarily due to powder composition. The MACP substituted for ripened cheese; therefore, MACP had lower fat content, which increased its densities. Furthermore, maltodextrins and constituents of whey such as globular proteins and lactose might increase the stability of fat emulsions during processing, which decreases the free fat content and improves the reconstitution properties of powders. The results shown in Table 3 are in agreement with the literature. It is reported that different food powders have bulk densities in the range of 300 to $800 \mathrm{~kg} / \mathrm{m}^{3}$ and skim milk has a bulk density of 400 to $450 \mathrm{~kg} / \mathrm{m}^{3}$ (Kelly et al., 2002; Barbosa-Canovas et al., 2005; Schuck, 2011). Furthermore, our results showed that the decrease in free fat content affected the reconstitution properties in a positive direction (Thomas et al., 2004; Schuck, 2007; Kim et al., 2009). It is well known that particle structure influences the physical properties of powders. The scanning electron micrographs show that the MACP particles had larger and more spherical structures with wrinkled surfaces (Figures 1 and 2), whereas other samples had shrunken and irregularly shaped particles 
with deep surface dents. Moreover, some damaged and cracked or fractured particles were observed in $\mathrm{CON}$ and WACP. The control cheese powder had the smoothest surface, which indicated a high surface fat content. Additionally, we detected a tendency for agglomeration and caking in some particles of CON and WACP samples, which is a result of high surface fat content. The presence of milk fat directly influenced the agglomeration of dairy powder particles. Further, liquid fat augmented the contact area between particles and created inter-particle liquid bridges that became solid due to fat crystallization (Thomas et al., 2004). The scanning electron micrographs and physicochemical analyses were in good agreement with this explanation (Figure 2). Additionally, powder samples were analyzed by DSC to predict the glass transition temperatures of the samples. However, the glass transition temperatures could not be clearly determined, as the powders contained low amounts of lactose. We detected a very distinct transition from 15 to $30^{\circ} \mathrm{C}$ due to the melting of fat (data not shown), as reported in the literature for high-fat dairy powders. The glass transition temperatures and dominant fat melting endotherm are in the same temperature range (Jouppila and Roos, 1994; Fitzpatrick et al., 2007).

\section{Effects of Storage on Physical Quality Parameters of Cheese Powder}

The moisture content, $\mathrm{pH}$, titratable acidity, and water activity changes of cheese powder samples during storage are shown in Table 4. The packaging material used in the study was a 3-layered material composed of polyethylene terephthalate/aluminum/low-density polyethylene and with a very low moisture permeability. The effectiveness of the packaging material was demonstrated by its ability to retain moisture, and the moisture contents of samples did not change significantly during storage $(P<0.05)$. On the other hand, water activity values increased with time for all samples. We observed the greatest increase for WACP during storage and the water activity of WACP was 0.238 after 12 mo of storage. Water activity is a thermodynamic term related to chemical potential of water. Although the chemical reaction rates are low at low water activity values for cheese powders, some variation may occur during storage, such as nonenzymatic browning or fat oxidation. These reactions may change the moisture availability in the powder. For instance, water is released during the initial steps in Maillard reactions, whereas water is consumed as a reactant in later steps (Bell, 2007). Moreover, the vaporization enthalpy is lower due to transition from strongly "bound" water to capillary water at water activity values higher than 0.2 (Barbosa-Canovas and Juliano, 2007). Finally, fats are generally hydrophobic and do not contribute significantly to moisture adsorption (Labuza and Altunakar, 2007). These may explain the increase in water activity with no significant change in moisture content during storage. Samples were in the safe zone as regards microbial growth risk. Changes in the acidity of the samples were monitored with $\mathrm{pH}$ and titratable acidity values (Table 4). The $\mathrm{pH}$ and titratable acidity results were in agreement: both analyses indicated slight increases in acidity of powders during storage.

The results of color measurements are presented in Table 5. Although the $L$ values of $\mathrm{CON}$ and WACP increased, a nonsignificant increase was observed for MACP $(P>0.05)$. Moreover, we detected significant decrease in $a$ values and increase in $b$ values for all cheese powder samples during storage $(P<0.05)$. The increase in $b$ values represented an increase in yellowness, perhaps due to the nonenzymatic browning reactions that occur during storage of dairy powders. Colorimetric measurements ( $L, a, b$ values) may provide information about the degree of Maillard reactions

Table 3. Physical and physicochemical features (mean \pm SD) of cheese powders with different formulations

\begin{tabular}{|c|c|c|c|}
\hline \multirow[b]{2}{*}{ Item } & \multicolumn{3}{|c|}{ Sample $^{1}$} \\
\hline & $\mathrm{CON}$ & WACP & MACP \\
\hline Water activity & $0.159 \pm 0.019^{\mathrm{a}}$ & $0.134 \pm 0.003^{\mathrm{a}}$ & $0.147 \pm 0.011^{\mathrm{a}}$ \\
\hline Bulk density $\left(\mathrm{kg} / \mathrm{m}^{3}\right)$ & $273.3 \pm 3.3^{\mathrm{a}}$ & $302.2 \pm 2.7^{\mathrm{b}}$ & $333.8 \pm 2.7^{\mathrm{c}}$ \\
\hline Tapped density $\left(\mathrm{kg} / \mathrm{m}^{3}\right)$ & $513.4 \pm 6.8^{\mathrm{a}}$ & $566.3 \pm 3.2^{\mathrm{b}}$ & $644.9 \pm 3.2^{\mathrm{c}}$ \\
\hline Particle density $\left(\mathrm{kg} / \mathrm{m}^{3}\right)$ & $1,251.2 \pm 2.9^{\mathrm{a}}$ & $1,308.5 \pm 8.8^{\mathrm{b}}$ & $1,353.9 \pm 7.4^{\mathrm{c}}$ \\
\hline Wettability (s) & $132.9 \pm 9.1^{\mathrm{c}}$ & $44.4 \pm 3.5^{\mathrm{b}}$ & $5.4 \pm 1.0^{\mathrm{a}}$ \\
\hline Dispersibility (\%) & $57.93 \pm 0.89^{\mathrm{a}}$ & $63.32 \pm 0.93^{\mathrm{b}}$ & $69.14 \pm 1.15^{\mathrm{c}}$ \\
\hline Solubility index (\%) & $76.95 \pm 0.42^{\mathrm{a}}$ & $79.91 \pm 0.55^{\mathrm{b}}$ & $82.27 \pm 1.02^{\mathrm{c}}$ \\
\hline Free fat content $(\%)$ & $42.34 \pm 0.28^{\mathrm{a}}$ & $36.39 \pm 1.19^{\mathrm{b}}$ & $27.78 \pm 0.27^{\mathrm{c}}$ \\
\hline
\end{tabular}



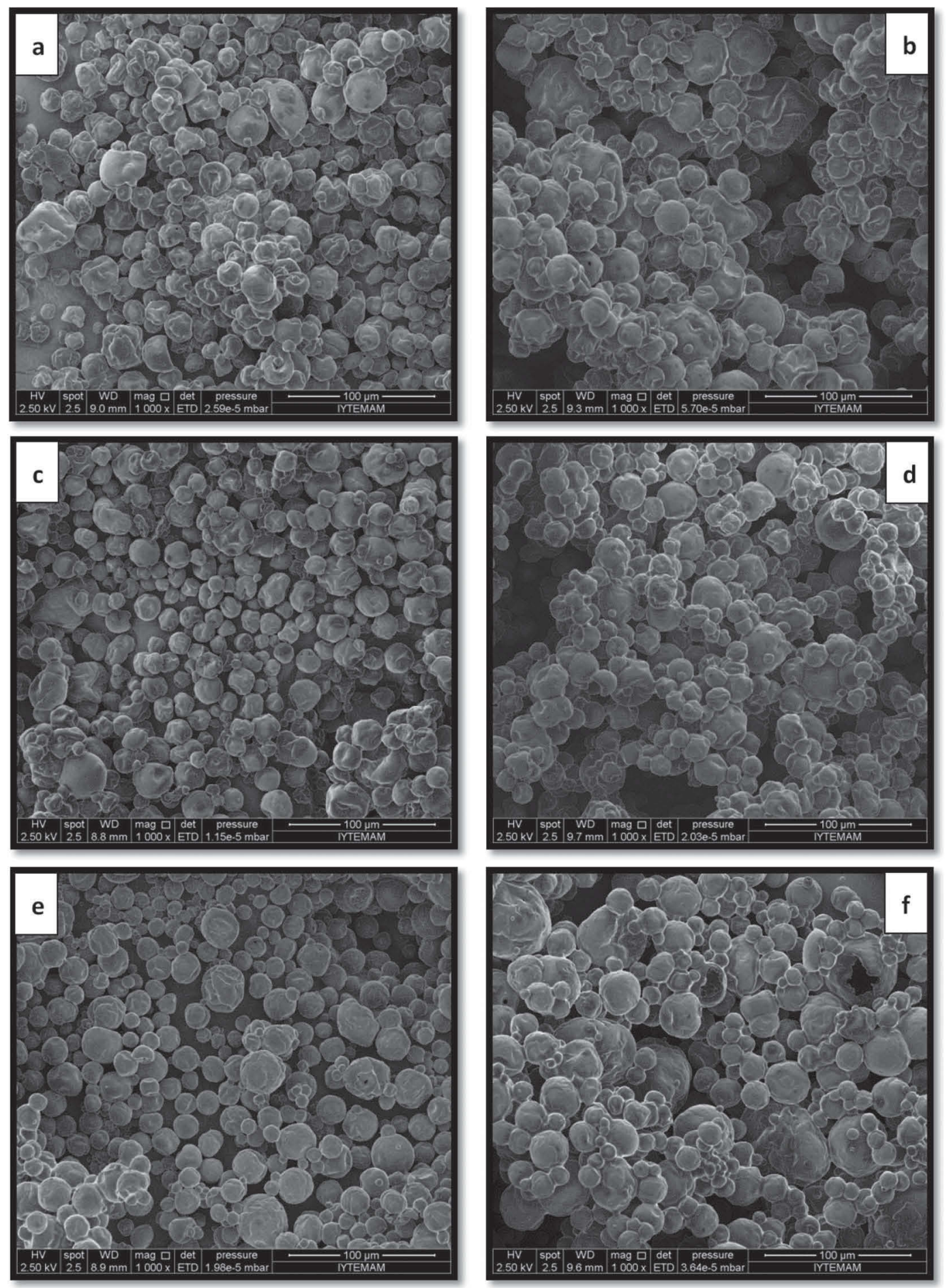

Figure 1. Scanning electron micrographs $(1,000 \times$ magnification) of cheese powders produced with different formulations for (a) control cheese powder $(\mathrm{CON})$ at 0 mo of storage, (b) CON at 12 mo of storage, (c) whey-added cheese powder (WACP) at 0 mo of storage, (d) WACP at 12 mo of storage, (e) maltodextrin-added cheese powder (MACP) at 0 mo of storage, and (f) MACP at 12 mo of storage.

(Stapelfeldt et al., 1997). In addition to primary color measurements, chroma and BI values were calculated and results are shown in Table 5. We obtained similar results for both color parameters. All cheese powder samples differed at all stages of storage and both chroma and BI values increased significantly with storage 

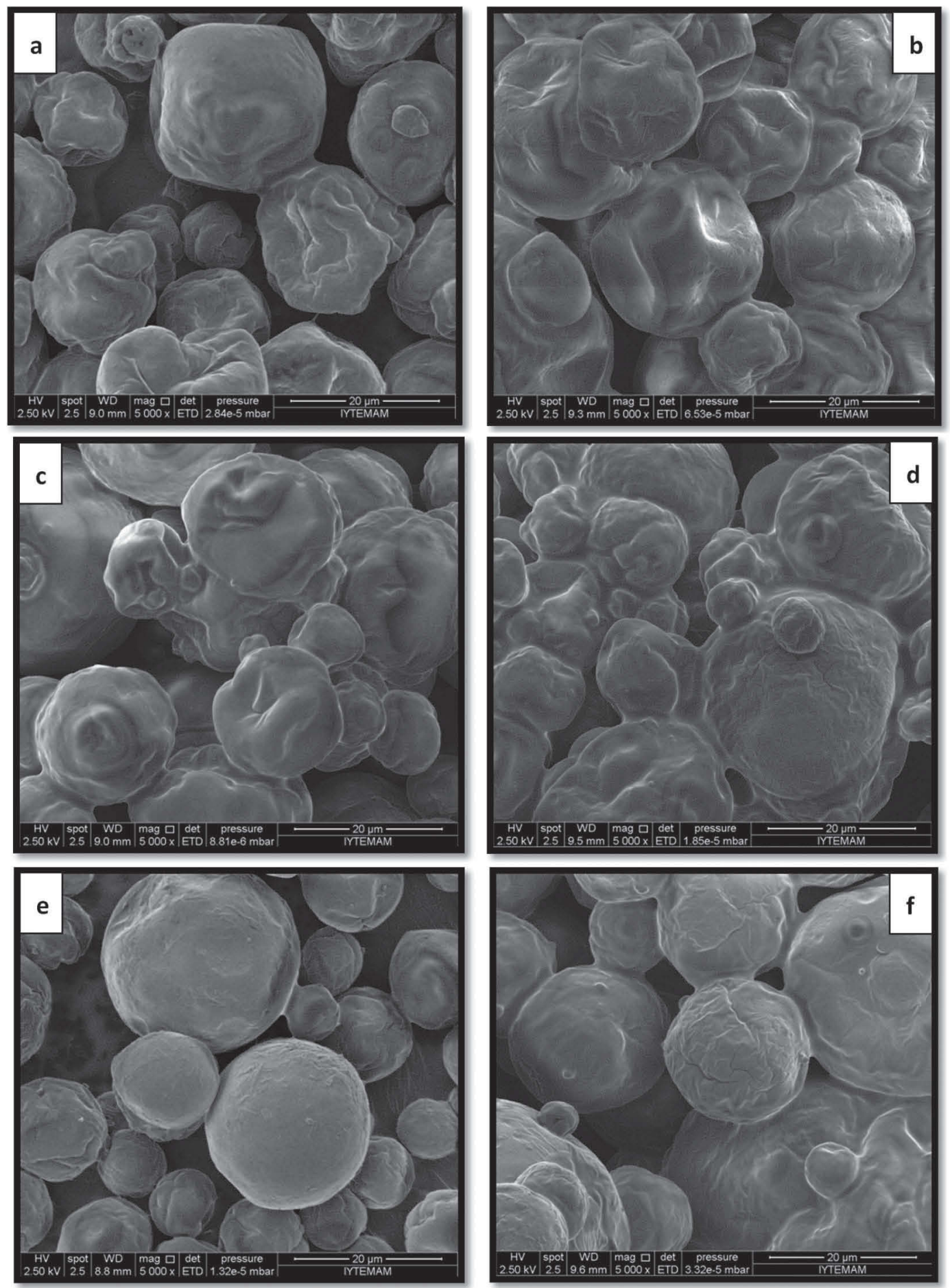

Figure 2. Scanning electron micrographs $(5,000 \times$ magnification) of cheese powders produced with different formulations for (a) control cheese powder (CON) at 0 mo of storage, (b) CON at 12 mo of storage, (c) whey-added cheese powder (WACP) at 0 mo of storage, (d) WACP at 12 mo of storage, (e) maltodextrin-added cheese powder (MACP) at 0 mo of storage, and (f) MACP at 12 mo of storage.

time $(P<0.05)$. The highest chroma and BI values were calculated for WACP and the lowest for CON. We concluded that variations in chroma and BI values mainly depended on $b$ values.
Other measured physical properties of cheese powders were the bulk, tapped, and particle densities, and results are listed in Table 6 . We observed that all density parameters showed similar tendencies with dif- 
Table 4. Moisture content, $\mathrm{pH}$, titratable acidity, and water activity values (means $\pm \mathrm{SD}$ ) of cheese powders during storage

\begin{tabular}{|c|c|c|c|c|}
\hline \multirow[b]{2}{*}{ Item } & \multirow{2}{*}{$\begin{array}{l}\text { Storage } \\
(\mathrm{mo})\end{array}$} & \multicolumn{3}{|c|}{ Sample $^{1}$} \\
\hline & & $\mathrm{CON}$ & WACP & MACP \\
\hline \multirow[t]{5}{*}{ Moisture content (\%) } & 0 & $2.27 \pm 0.12^{\mathrm{a}, \mathrm{A}}$ & $2.72 \pm 0.22^{\mathrm{b}, \mathrm{A}}$ & $2.13 \pm 0.05^{\mathrm{a}, \mathrm{A}}$ \\
\hline & 3 & $2.20 \pm 0.14^{\mathrm{a}, \mathrm{A}}$ & $2.56 \pm 0.20^{\mathrm{b}, \mathrm{A}}$ & $2.10 \pm 0.14^{\mathrm{a}, \mathrm{A}}$ \\
\hline & 6 & $2.31 \pm 0.11^{\mathrm{ab}, \mathrm{A}}$ & $2.49 \pm 0.19^{\mathrm{b}, \mathrm{A}}$ & $2.10 \pm 0.11^{\mathrm{a}, \mathrm{A}}$ \\
\hline & 9 & $2.33 \pm 0.13^{\mathrm{ab}, \mathrm{A}}$ & $2.58 \pm 0.23^{\mathrm{b}, \mathrm{A}}$ & $2.19 \pm 0.13^{\mathrm{a}, \mathrm{A}}$ \\
\hline & 12 & $2.30 \pm 0.15^{\mathrm{ab}, \mathrm{A}}$ & $2.60 \pm 0.29^{\mathrm{b}, \mathrm{A}}$ & $2.07 \pm 0.08^{\mathrm{a}, \mathrm{A}}$ \\
\hline \multirow[t]{5}{*}{$\mathrm{pH}$} & 0 & $5.37 \pm 0.01^{\mathrm{a}, \mathrm{A}}$ & $5.40 \pm 0.01^{\mathrm{b}, \mathrm{A}}$ & $5.48 \pm 0.01^{\mathrm{c}, \mathrm{B}}$ \\
\hline & 3 & $5.38 \pm 0.02^{\mathrm{a}, \mathrm{A}}$ & $5.40 \pm 0.03^{\mathrm{a}, \mathrm{A}}$ & $5.51 \pm 0.02^{\mathrm{b}, \mathrm{A}}$ \\
\hline & 6 & $5.36 \pm 0.01^{\mathrm{a}, \mathrm{A}}$ & $5.36 \pm 0.03^{\mathrm{a}, \mathrm{A}}$ & $5.45 \pm 0.02^{\mathrm{b}, \mathrm{C}}$ \\
\hline & 9 & $5.34 \pm 0.01^{\mathrm{a}, \mathrm{B}}$ & $5.30 \pm 0.04^{\mathrm{a}, \mathrm{B}}$ & $5.42 \pm 0.01^{\mathrm{b}, \mathrm{D}}$ \\
\hline & 12 & $5.32 \pm 0.02^{\mathrm{b}, \mathrm{C}}$ & $5.26 \pm 0.04^{\mathrm{a}, \mathrm{C}}$ & $5.39 \pm 0.02^{\mathrm{c}, \mathrm{E}}$ \\
\hline \multirow[t]{5}{*}{ Titratable acidity (\%) } & 0 & $4.370 \pm 0.029^{\mathrm{a}, \mathrm{A}}$ & $4.167 \pm 0.019^{\mathrm{b}, \mathrm{A}}$ & $3.135 \pm 0.026^{\mathrm{c}, \mathrm{B}}$ \\
\hline & 3 & $4.383 \pm 0.013^{\mathrm{a}, \mathrm{A}}$ & $4.184 \pm 0.134^{\mathrm{b}, \mathrm{A}}$ & $3.018 \pm 0.049^{\mathrm{c}, \mathrm{A}}$ \\
\hline & 6 & $4.546 \pm 0.030^{\mathrm{b}, \mathrm{B}}$ & $4.739 \pm 0.202^{\mathrm{a}, \mathrm{B}}$ & $3.744 \pm 0.019^{\mathrm{c}, \mathrm{C}}$ \\
\hline & 9 & $4.874 \pm 0.031^{\mathrm{b}, \mathrm{C}}$ & $5.170 \pm 0.112^{\mathrm{a}, \mathrm{C}}$ & $4.152 \pm 0.020^{\mathrm{c}, \mathrm{D}}$ \\
\hline & 12 & $5.159 \pm 0.045^{\mathrm{b}, \mathrm{D}}$ & $5.355 \pm 0.105^{\mathrm{a}, \mathrm{C}}$ & $4.545 \pm 0.048^{\mathrm{c}, \mathrm{E}}$ \\
\hline \multirow{5}{*}{ Water activity } & 0 & $0.159 \pm 0.019^{\mathrm{a}, \mathrm{AB}}$ & $0.134 \pm 0.003^{\mathrm{a}, \mathrm{A}}$ & $0.147 \pm 0.011^{\mathrm{a}, \mathrm{A}}$ \\
\hline & 3 & $0.149 \pm 0.010^{\mathrm{a}, \mathrm{A}}$ & $0.155 \pm 0.015^{\mathrm{a}, \mathrm{AB}}$ & $0.146 \pm 0.001^{\mathrm{a}, \mathrm{A}}$ \\
\hline & 6 & $0.179 \pm 0.003^{\mathrm{a}, \mathrm{BC}}$ & $0.202 \pm 0.033^{\mathrm{a}, \mathrm{BC}}$ & $0.162 \pm 0.009^{\mathrm{a}, \mathrm{AB}}$ \\
\hline & 9 & $0.193 \pm 0.009^{\mathrm{a}, \mathrm{CD}}$ & $0.210 \pm 0.036^{\mathrm{a}, \mathrm{BC}}$ & $0.168 \pm 0.010^{\mathrm{a}, \mathrm{B}}$ \\
\hline & 12 & $0.218 \pm 0.002^{\mathrm{ab}, \mathrm{D}}$ & $0.238 \pm 0.041^{\mathrm{b}, \mathrm{C}}$ & $0.170 \pm 0.001^{\mathrm{a}, \mathrm{B}}$ \\
\hline
\end{tabular}

${ }^{\mathrm{a}-\mathrm{c}}$ Means within a row with different superscripts differ $(P<0.05)$.

${ }^{\mathrm{A}-\mathrm{E}}$ Means within a column for a given item with different superscripts differ $(P<0.05)$.

${ }^{1} \mathrm{CON}=$ control cheese powder, WACP $=$ whey-added cheese powder, $\mathrm{MACP}=$ maltodextrin-added cheese powder.

Table 5. Color characteristics (mean $\pm \mathrm{SD}$ ) of cheese powders during storage

\begin{tabular}{|c|c|c|c|c|}
\hline \multirow[b]{2}{*}{ Item $^{1}$} & \multirow{2}{*}{$\begin{array}{l}\text { Storage } \\
(\mathrm{mo})\end{array}$} & \multicolumn{3}{|c|}{ Sample $^{2}$} \\
\hline & & $\mathrm{CON}$ & WACP & MACP \\
\hline \multirow[t]{5}{*}{$L$} & 0 & $95.35 \pm 0.10^{\mathrm{a}, \mathrm{A}}$ & $94.56 \pm 0.12^{\mathrm{c}, \mathrm{A}}$ & $95.13 \pm 0.11^{\mathrm{b}, \mathrm{A}}$ \\
\hline & 3 & $95.56 \pm 0.13^{\mathrm{a}, \mathrm{AB}}$ & $94.56 \pm 0.13^{\mathrm{c}, \mathrm{A}}$ & $94.94 \pm 0.15^{\mathrm{b}, \mathrm{A}}$ \\
\hline & 6 & $95.56 \pm 0.12^{\mathrm{a}, \mathrm{AB}}$ & $94.48 \pm 0.21^{\mathrm{c}, \mathrm{A}}$ & $94.91 \pm 0.28^{\mathrm{b}, \mathrm{A}}$ \\
\hline & 9 & $95.65 \pm 0.23^{\mathrm{a}, \mathrm{B}}$ & $94.90 \pm 0.23^{\mathrm{b}, \mathrm{B}}$ & $95.05 \pm 0.30^{\mathrm{b}, \mathrm{A}}$ \\
\hline & 12 & $95.66 \pm 0.09^{\mathrm{a}, \mathrm{B}}$ & $94.87 \pm 0.22^{\mathrm{b}, \mathrm{B}}$ & $94.83 \pm 0.27^{\mathrm{b}, \mathrm{A}}$ \\
\hline \multirow[t]{5}{*}{$a$} & 0 & $0.87 \pm 0.05^{\mathrm{a}, \mathrm{A}}$ & $0.75 \pm 0.04^{\mathrm{b}, \mathrm{A}}$ & $0.94 \pm 0.03^{\mathrm{a}, \mathrm{A}}$ \\
\hline & 3 & $0.76 \pm 0.07^{\mathrm{a}, \mathrm{B}}$ & $0.64 \pm 0.05^{\mathrm{b}, \mathrm{B}}$ & $0.73 \pm 0.03^{\mathrm{a}, \mathrm{B}}$ \\
\hline & 6 & $0.63 \pm 0.02^{\mathrm{a}, \mathrm{C}}$ & $0.54 \pm 0.08^{\mathrm{a}, \mathrm{AB}}$ & $0.59 \pm 0.03^{\mathrm{a}, \mathrm{C}}$ \\
\hline & 9 & $0.64 \pm 0.06^{\mathrm{a}, \mathrm{C}}$ & $0.56 \pm 0.10^{\mathrm{a}, \mathrm{AB}}$ & $0.61 \pm 0.05^{\mathrm{a}, \mathrm{C}}$ \\
\hline & 12 & $0.64 \pm 0.02^{\mathrm{a}, \mathrm{C}}$ & $0.51 \pm 0.02^{\mathrm{b}, \mathrm{C}}$ & $0.43 \pm 0.01^{\mathrm{c}, \mathrm{D}}$ \\
\hline \multirow[t]{5}{*}{$b$} & 0 & $9.28 \pm 0.10^{\mathrm{a}, \mathrm{A}}$ & $10.11 \pm 0.20^{\mathrm{c}, \mathrm{A}}$ & $9.71 \pm 0.05^{\mathrm{b}, \mathrm{A}}$ \\
\hline & 3 & $9.57 \pm 0.09^{\mathrm{a}, \mathrm{B}}$ & $10.44 \pm 0.14^{\mathrm{c}, \mathrm{B}}$ & $9.93 \pm 0.14^{\mathrm{b}, \mathrm{AB}}$ \\
\hline & 6 & $9.62 \pm 0.24^{\mathrm{a}, \mathrm{B}}$ & $10.76 \pm 0.19^{\mathrm{c}, \mathrm{C}}$ & $10.01 \pm 0.20^{\mathrm{b}, \mathrm{B}}$ \\
\hline & 9 & $9.69 \pm 0.15^{\mathrm{a}, \mathrm{B}}$ & $10.97 \pm 0.11^{\mathrm{c}, \mathrm{CD}}$ & $10.26 \pm 0.14^{\mathrm{b}, \mathrm{C}}$ \\
\hline & 12 & $10.09 \pm 0.11^{\mathrm{a}, \mathrm{C}}$ & $11.07 \pm 0.14^{\mathrm{c}, \mathrm{D}}$ & $10.69 \pm 0.16^{\mathrm{b}, \mathrm{D}}$ \\
\hline \multirow[t]{5}{*}{ Chroma } & 0 & $9.32 \pm 0.10^{\mathrm{a}, \mathrm{A}}$ & $10.14 \pm 0.20^{\mathrm{c}, \mathrm{A}}$ & $9.76 \pm 0.05^{\mathrm{b}, \mathrm{A}}$ \\
\hline & 3 & $9.60 \pm 0.09^{\mathrm{a}, \mathrm{B}}$ & $10.46 \pm 0.14^{\mathrm{c}, \mathrm{B}}$ & $9.95 \pm 0.14^{\mathrm{b}, \mathrm{AB}}$ \\
\hline & 6 & $9.64 \pm 0.24^{\mathrm{a}, \mathrm{B}}$ & $10.77 \pm 0.19^{\mathrm{c}, \mathrm{C}}$ & $10.02 \pm 0.20^{\mathrm{b}, \mathrm{B}}$ \\
\hline & 9 & $9.71 \pm 0.15^{\mathrm{a}, \mathrm{B}}$ & $10.98 \pm 0.11^{\mathrm{c}, \mathrm{CD}}$ & $10.28 \pm 0.15^{\mathrm{b}, \mathrm{C}}$ \\
\hline & 12 & $10.11 \pm 0.11^{\mathrm{a}, \mathrm{C}}$ & $11.08 \pm 0.14^{\mathrm{c}, \mathrm{D}}$ & $10.70 \pm 0.16^{\mathrm{b}, \mathrm{D}}$ \\
\hline \multirow[t]{5}{*}{ BI } & 0 & $10.67 \pm 0.07^{\mathrm{a}, \mathrm{A}}$ & $11.62 \pm 0.25^{\mathrm{c}, \mathrm{A}}$ & $11.25 \pm 0.07^{\mathrm{b}, \mathrm{A}}$ \\
\hline & 3 & $10.89 \pm 0.10^{\mathrm{a}, \mathrm{A}}$ & $11.92 \pm 0.19^{\mathrm{c}, \mathrm{B}}$ & $11.35 \pm 0.11^{\mathrm{b}, \mathrm{A}}$ \\
\hline & 6 & $10.85 \pm 0.28^{\mathrm{a}, \mathrm{A}}$ & $12.23 \pm 0.20^{\mathrm{c}, \mathrm{C}}$ & $11.34 \pm 0.26^{\mathrm{b}, \mathrm{A}}$ \\
\hline & 9 & $10.92 \pm 0.11^{\mathrm{a}, \mathrm{A}}$ & $12.42 \pm 0.21^{\mathrm{c}, \mathrm{C}}$ & $11.62 \pm 0.23^{\mathrm{b}, \mathrm{B}}$ \\
\hline & 12 & $11.37 \pm 0.14^{\mathrm{a}, \mathrm{B}}$ & $12.50 \pm 0.12^{\mathrm{c}, \mathrm{C}}$ & $12.02 \pm 0.15^{\mathrm{b}, \mathrm{C}}$ \\
\hline
\end{tabular}

${ }^{\mathrm{a}-\mathrm{c}}$ Means within a row with different superscripts differ $(P<0.05)$.

${ }^{\mathrm{A}-\mathrm{D}}$ Means within a column for a given item with different superscripts differ $(P<0.05)$.

${ }^{1} L=$ lightness-darkness; $a=$ red-green color; $b=$ yellow-blue color; $\mathrm{BI}=$ browning index.

${ }^{2} \mathrm{CON}=$ control cheese powder, $\mathrm{WACP}=$ whey-added cheese powder, $\mathrm{MACP}=$ maltodextrin-added cheese powder. 
Table 6. Densities (mean $\pm \mathrm{SD}$ ) of cheese powders during storage

\begin{tabular}{|c|c|c|c|c|}
\hline \multirow[b]{2}{*}{ Item } & \multirow{2}{*}{$\begin{array}{l}\text { Storage } \\
(\mathrm{mo})\end{array}$} & \multicolumn{3}{|c|}{ Sample $^{1}$} \\
\hline & & $\mathrm{CON}$ & WACP & MACP \\
\hline \multirow[t]{5}{*}{ Bulk density $\left(\mathrm{kg} / \mathrm{m}^{3}\right)$} & 0 & $273.3 \pm 3.3^{\mathrm{a}, \mathrm{A}}$ & $302.2 \pm 2.7^{\mathrm{b}, \mathrm{A}}$ & $333.8 \pm 2.7^{\mathrm{c}, \mathrm{A}}$ \\
\hline & 3 & $273.7 \pm 3.9^{\mathrm{a}, \mathrm{A}}$ & $297.4 \pm 2.0^{\mathrm{b}, \mathrm{AB}}$ & $326.6 \pm 5.4^{\mathrm{c}, \mathrm{AB}}$ \\
\hline & 6 & $269.9 \pm 1.6^{\mathrm{a}, \mathrm{A}}$ & $296.4 \pm 3.7^{\mathrm{b}, \mathrm{B}}$ & $324.4 \pm 3.7^{\mathrm{c}, \mathrm{B}}$ \\
\hline & 9 & $273.8 \pm 2.9^{\mathrm{a}, \mathrm{A}}$ & $301.7 \pm 3.3^{\mathrm{b}, \mathrm{A}}$ & $327.9 \pm 7.1^{\mathrm{c}, \mathrm{AB}}$ \\
\hline & 12 & $272.7 \pm 2.4^{\mathrm{a}, \mathrm{A}}$ & $301.8 \pm 3.6^{\mathrm{b}, \mathrm{A}}$ & $324.0 \pm 5.7^{\mathrm{c}, \mathrm{B}}$ \\
\hline \multirow[t]{5}{*}{ Tapped density $\left(\mathrm{kg} / \mathrm{m}^{3}\right)$} & 0 & $513.4 \pm 6.8^{\mathrm{a}, \mathrm{A}}$ & $566.3 \pm 3.2^{\mathrm{b}, \mathrm{A}}$ & $644.9 \pm 3.2^{\mathrm{c}, \mathrm{AB}}$ \\
\hline & 3 & $525.0 \pm 5.4^{\mathrm{a}, \mathrm{B}}$ & $563.9 \pm 1.7^{\mathrm{b}, \mathrm{AB}}$ & $649.9 \pm 6.8^{\mathrm{c}, \mathrm{A}}$ \\
\hline & 6 & $520.3 \pm 3.2^{\mathrm{a}, \mathrm{AB}}$ & $555.4 \pm 5.5^{\mathrm{b}, \mathrm{B}}$ & $637.8 \pm 6.8^{\mathrm{c}, \mathrm{BC}}$ \\
\hline & 9 & $519.1 \pm 8.6^{\mathrm{a}, \mathrm{AB}}$ & $558.7 \pm 4.5^{\mathrm{b}, \mathrm{AB}}$ & $633.7 \pm 8.7^{\mathrm{c}, \mathrm{C}}$ \\
\hline & 12 & $520.8 \pm 8.5^{\mathrm{a}, \mathrm{AB}}$ & $560.5 \pm 12.1^{\mathrm{b}, \mathrm{AB}}$ & $645.0 \pm 7.0^{\mathrm{c}, \mathrm{AB}}$ \\
\hline \multirow[t]{5}{*}{ Particle density $\left(\mathrm{kg} / \mathrm{m}^{3}\right)$} & 0 & $1,251.2 \pm 2.9^{\mathrm{a}, \mathrm{A}}$ & $1,308.5 \pm 8.8^{\mathrm{b}, \mathrm{A}}$ & $1,353.9 \pm 7.4^{\mathrm{c}, \mathrm{A}}$ \\
\hline & 3 & $1,248.4 \pm 10.0^{\mathrm{a}, \mathrm{A}}$ & $1,300.3 \pm 10.3^{\mathrm{b}, \mathrm{A}}$ & $1,355.5 \pm 11.2^{\mathrm{c}, \mathrm{A}}$ \\
\hline & 6 & $1,252.1 \pm 7.6^{\mathrm{a}, \mathrm{A}}$ & $1,301.1 \pm 8.2^{\mathrm{b}, \mathrm{A}}$ & $1.354 .7 \pm 8.9^{\mathrm{c}, \mathrm{A}}$ \\
\hline & 9 & $1,253.2 \pm 6.3^{\mathrm{a}, \mathrm{A}}$ & $1,302.0 \pm 7.2^{\mathrm{b}, \mathrm{A}}$ & $1,351.7 \pm 6.4^{\mathrm{c}, \mathrm{A}}$ \\
\hline & 12 & $1.252 .1 \pm 5.9^{\mathrm{a}, \mathrm{A}}$ & $1.304 .3 \pm 4.8^{\mathrm{b}, \mathrm{A}}$ & $1.354 .0 \pm 5.7^{\mathrm{c}, \mathrm{A}}$ \\
\hline
\end{tabular}

${ }^{\mathrm{a}-\mathrm{c}}$ Means within a row with different superscripts differ $(P<0.05)$.

${ }^{\mathrm{A}-\mathrm{C}}$ Means within a column for a given item with different superscripts differ $(P<0.05)$.

${ }^{1} \mathrm{CON}=$ control cheese powder, WACP $=$ whey-added cheese powder, $\mathrm{MACP}=$ maltodextrin-added cheese powder.

ferent formulations and with storage time. The highest densities were measured for MACP, followed by WACP $(P<0.05)$. In contrast, changes in densities during storage for each powder were not significant $(P>0.05)$. It is well known that bulk density is mainly related to powder composition. An increase in moisture content and decrease in fat content cause a decrease in bulk density of powders (Kelly et al., 2002; Barbosa-Canovas et al., 2005; Schuck, 2011). The results of the present study showed that the major effect on bulk density values was the fat content of powders. The stability of bulk densities during storage was due to the unchanged ratio of moisture in the powders.

The values of reconstitution properties and free fat contents of cheese powders are shown in Table 7. Wettability is one of the major properties in reconstitution, and all powder samples differed significantly in all storage stages $(P<0.05)$ : MACP was the most wettable powder sample, whereas $\mathrm{CON}$ was the least. Although the wettabilities of MACP and WACP slightly decreased during storage, that of CON increased $(P<0.05)$. However, the decrease in MACP was unimportant in practical terms. It has been reported in the literature that wettability depends mainly on free or surface fat (Kim et al., 2002, 2009). The increase in fat content causes an increase in free fat content together with surface fat content of dairy powders (Kim et al., 2002, 2009). Because of the increase in surface free fat, the powder surface becomes hydrophobic with a large contact angle between the powder surface and the penetrating water and deteriorates the wettability of dairy powder (Kim et al., 2002, 2009). Similar results were obtained in the present study. We observed that the fat and free fat contents of CON were notably higher, whereas the wettabilities were lower than all other powders (Table 7). In addition to fat content, protein content on the surface of powders negatively influences wettability, whereas lactose content on the surface increases wettability (Gaiani et al., 2006). Our results were in line with the literature, and wettability decreased with the increase in protein content (Tables 1 and 7). Another important factor that affected wettability was particle size. An increase in particle size causes an increase in wettability (Freudig et al., 1999; Martins and Kieckbusch, 2008, 2010). Additionally, powder samples with high bulk densities are known to be more sinkable. We observed that MACP samples, which were the most wettable powders, had larger particles and higher bulk densities (Figures 1 and 2, Table 6).

The variation of dispersibilities of cheese powder samples during storage were not significant $(P>0.05)$, whereas the variation in powder formulation affected dispersabilities significantly $(P<0.05)$. Similar to the wettability results of the present study and the literature, the highest dispersibility was obtained for MACP samples (Table 7; Thomas et al., 2004; Schuck, 2007; Kim et al., 2009).

The solubilities of cheese powder samples were different at all storage stages due to the different formulations $(P<0.05)$. The MACP powder had the highest solubility, followed by WACP, and CON had the lowest values (Table 7), mainly because of differences in the composition of powders. Maltodextrin (in MACP) is a highly soluble component. Similarly, WACP con- 
tained a hydrophilic component (lactose) and globular proteins, which are more soluble than casein. Because of this, WACP samples had higher solubility index values than CON. However, it has been reported that polymerization of whey proteins occurs during storage, thereby decreasing solubility (Stapelfeldt et al., 1997). Moreover, decreases in $\mathrm{pH}$ cause a decrease in whey protein solubility (Thomas et al., 2004). The solubility of WACP did not change significantly, whereas that of CON increased during storage (Table 7). Another important factor that influenced the solubility of cheese powders was the fat content; we observed low solubility for samples with high fat content.

All powders at all storage stages were statistically different $(P<0.05)$ in free fat content. The composition of dairy powders influenced free fat content. Increases in fat and protein contents and decreases in lactose content increase the free fat content of dairy powders (Keogh et al., 2002). Moreover, particle size affects free fat content; smaller particles result in greater surface area and increased free fat content (Keogh et al., 2002; Park and Drake, 2014). Our results were in agreement with the literature, and MACP samples with low fat and protein contents had the lowest free fat contents. Further, WACP contained lactose and had lower free fat content than CON. We compared the free fat content per fat content ratio of powders and the results were in accordance with the literature. At the beginning of storage, CON, WACP, and MACP had 86.8 to $87.1 \%$, 82.6 to $87.2 \%$, and 76.8 to $78.9 \%$ free fat content per fat content ratios, whereas the ratios were 89.7 to $90.3 \%$, 87.4 to $89.7 \%$, and 80.1 to $81.8 \%$ at mo 12 of storage, respectively.

Scanning electron micrographs of cheese powder samples at the beginning and the end of the storage periods are shown in Figures 1 and 2. After 12 mo of storage, we determined adhesion of powder particles, especially for WACP and CON, as mentioned above. Scanning electron micrographs of particle surfaces revealed the caking tendency. However, the degree of caking was insufficient for sensory determination and the variation of caking during storage detected by scanning electron microscopy was deemed insignificant due to the sensory analysis (Table 8).

Panelists did not determine a difference due to storage or formulation variations for caking and color properties $(P>0.05)$. Panelists defined the cheese powders as "slightly caked" and as "colored between white and cream." Color differences were due to powder formulation and variation in $b$ values during storage (Table $5)$. However, these variations were small and were not perceived by panelists. Although panelists did not identify significant differences in flowability of powders during storage $(P>0.05)$, they detected a small difference between MACP and other powders $(P<0.05)$; CON and WACP were defined as "slightly flowable,"

Table 7. Reconstitution properties and free fat contents (mean \pm SD) of cheese powders during storage

\begin{tabular}{|c|c|c|c|c|}
\hline \multirow[b]{2}{*}{ Item } & \multirow{2}{*}{$\begin{array}{l}\text { Storage } \\
(\mathrm{mo})\end{array}$} & \multicolumn{3}{|c|}{ Sample $^{1}$} \\
\hline & & $\mathrm{CON}$ & WACP & MACP \\
\hline \multirow[t]{5}{*}{ Wettability (s) } & 0 & $132.9 \pm 9.1^{\mathrm{a}, \mathrm{AB}}$ & $44.4 \pm 3.5^{\mathrm{b}, \mathrm{A}}$ & $5.4 \pm 1.0^{\mathrm{c}, \mathrm{A}}$ \\
\hline & 3 & $136.1 \pm 14.4^{\mathrm{a}, \mathrm{A}}$ & $54.7 \pm 6.4^{\mathrm{b}, \mathrm{B}}$ & $9.0 \pm 1.8^{\mathrm{c}, \mathrm{B}}$ \\
\hline & 6 & $134.1 \pm 7.0^{\mathrm{a}, \mathrm{AB}}$ & $62.7 \pm 7.9^{\mathrm{b}, \mathrm{C}}$ & $10.3 \pm 1.6^{\mathrm{c}, \mathrm{BC}}$ \\
\hline & 9 & $125.7 \pm 9.8^{\mathrm{a}, \mathrm{BC}}$ & $65.9 \pm 7.0^{\mathrm{b}, \mathrm{C}}$ & $11.1 \pm 1.7^{\mathrm{c}, \mathrm{C}}$ \\
\hline & 12 & $120.9 \pm 10.2^{\mathrm{a}, \mathrm{C}}$ & $67.9 \pm 6.6^{\mathrm{b}, \mathrm{C}}$ & $10.8 \pm 1.5^{\mathrm{c}, \mathrm{C}}$ \\
\hline \multirow[t]{5}{*}{ Dispersibility (\%) } & 0 & $57.93 \pm 0.89^{\mathrm{a}, \mathrm{A}}$ & $63.32 \pm 0.93^{\mathrm{b}, \mathrm{A}}$ & $69.14 \pm 1.15^{\mathrm{c}, \mathrm{A}}$ \\
\hline & 3 & $57.91 \pm 0.80^{\mathrm{a}, \mathrm{A}}$ & $63.45 \pm 1.02^{\mathrm{b}, \mathrm{A}}$ & $67.96 \pm 1.57^{\mathrm{c}, \mathrm{A}}$ \\
\hline & 6 & $58.47 \pm 1.28^{\mathrm{a}, \mathrm{A}}$ & $62.99 \pm 1.06^{\mathrm{b}, \mathrm{A}}$ & $68.63 \pm 1.85^{\mathrm{c}, \mathrm{A}}$ \\
\hline & 9 & $58.37 \pm 0.73^{\mathrm{a}, \mathrm{A}}$ & $63.09 \pm 0.76^{\mathrm{b}, \mathrm{A}}$ & $68.02 \pm 0.78^{\mathrm{c}, \mathrm{A}}$ \\
\hline & 12 & $58.54 \pm 0.52^{\mathrm{a}, \mathrm{A}}$ & $62.76 \pm 1.92^{\mathrm{b}, \mathrm{A}}$ & $67.65 \pm 1.16^{\mathrm{c}, \mathrm{A}}$ \\
\hline \multirow[t]{5}{*}{ Solubility index (\%) } & 0 & $76.95 \pm 0.42^{\mathrm{a}, \mathrm{A}}$ & $79.91 \pm 0.55^{\mathrm{b}, \mathrm{A}}$ & $82.27 \pm 1.02^{\mathrm{c}, \mathrm{A}}$ \\
\hline & 3 & $77.35 \pm 1.08^{\mathrm{a}, \mathrm{AB}}$ & $80.61 \pm 0.69^{\mathrm{b}, \mathrm{B}}$ & $83.06 \pm 0.75^{\mathrm{c}, \mathrm{A}}$ \\
\hline & 6 & $77.63 \pm 0.44^{\mathrm{a}, \mathrm{ABC}}$ & $80.08 \pm 0.38^{\mathrm{b}, \mathrm{AB}}$ & $82.86 \pm 0.50^{\mathrm{c}, \mathrm{A}}$ \\
\hline & 9 & $77.83 \pm 0.34^{\mathrm{a}, \mathrm{BC}}$ & $79.87 \pm 0.48^{\mathrm{b}, \mathrm{A}}$ & $82.42 \pm 0.32^{\mathrm{c}, \mathrm{A}}$ \\
\hline & 12 & $78.21 \pm 0.62^{\mathrm{a}, \mathrm{C}}$ & $79.50 \pm 0.46^{\mathrm{b}, \mathrm{A}}$ & $82.41 \pm 0.47^{\mathrm{c}, \mathrm{A}}$ \\
\hline \multirow[t]{5}{*}{ Free fat content (\%) } & 0 & $42.34 \pm 0.28^{\mathrm{a}, \mathrm{A}}$ & $36.39 \pm 1.19^{\mathrm{b}, \mathrm{A}}$ & $27.78 \pm 0.27^{\mathrm{c}, \mathrm{A}}$ \\
\hline & 3 & $42.86 \pm 0.55^{\mathrm{a}, \mathrm{B}}$ & $36.89 \pm 0.57^{\mathrm{b}, \mathrm{AB}}$ & $27.74 \pm 0.59^{\mathrm{c}, \mathrm{A}}$ \\
\hline & 6 & $43.25 \pm 0.42^{\mathrm{a}, \mathrm{B}}$ & $37.55 \pm 0.83^{\mathrm{b}, \mathrm{BC}}$ & $28.81 \pm 0.43^{\mathrm{c}, \mathrm{B}}$ \\
\hline & 9 & $44.25 \pm 0.33^{\mathrm{a}, \mathrm{C}}$ & $37.91 \pm 0.82^{\mathrm{b}, \mathrm{C}}$ & $28.53 \pm 0.36^{\mathrm{c}, \mathrm{B}}$ \\
\hline & 12 & $43.82 \pm 0.48^{\mathrm{a}, \mathrm{C}}$ & $37.95 \pm 0.85^{\mathrm{b}, \mathrm{C}}$ & $28.88 \pm 0.12^{\mathrm{c}, \mathrm{B}}$ \\
\hline
\end{tabular}


Table 8. Sensory determination (mean $\pm \mathrm{SD}$ ) of physical properties of cheese powders during storage ${ }^{1}$

\begin{tabular}{llccc}
\hline & & & \multicolumn{3}{c}{ Sample $^{2}$} \\
Item & Storage & & \\
\cline { 2 - 4 } & $(\mathrm{mo})$ & $\mathrm{CON}$ & WACP & MACP \\
\hline Caking & 0 & $3.00 \pm 0.86^{\mathrm{a}, \mathrm{A}}$ & $2.95 \pm 0.83^{\mathrm{a}, \mathrm{A}}$ & $2.70 \pm 0.66^{\mathrm{a}, \mathrm{A}}$ \\
& 3 & $2.85 \pm 0.67^{\mathrm{a}, \mathrm{A}}$ & $3.00 \pm 0.79^{\mathrm{a}, \mathrm{A}}$ & $2.80 \pm 0.77^{\mathrm{a}, \mathrm{A}}$ \\
& 6 & $2.85 \pm 0.75^{\mathrm{a}, \mathrm{A}}$ & $2.95 \pm 0.76^{\mathrm{a}, \mathrm{A}}$ & $3.20 \pm 0.62^{\mathrm{a}, \mathrm{A}}$ \\
& 9 & $3.10 \pm 0.91^{\mathrm{a}, \mathrm{A}}$ & $2.85 \pm 0.59^{\mathrm{a}, \mathrm{A}}$ & $3.05 \pm 0.83^{\mathrm{a}, \mathrm{A}}$ \\
& 12 & $3.05 \pm 0.89^{\mathrm{a}, \mathrm{A}}$ & $2.95 \pm 0.76^{\mathrm{a}, \mathrm{A}}$ & $3.00 \pm 0.73^{\mathrm{a}, \mathrm{A}}$ \\
Flowability & 0 & $3.10 \pm 0.97^{\mathrm{a}, \mathrm{A}}$ & $2.90 \pm 0.79^{\mathrm{a}, \mathrm{A}}$ & $4.15 \pm 1.04^{\mathrm{b}, \mathrm{A}}$ \\
& 3 & $2.85 \pm 1.04^{\mathrm{a}, \mathrm{A}}$ & $3.00 \pm 0.79^{\mathrm{a}, \mathrm{A}}$ & $4.05 \pm 1.00^{\mathrm{b}, \mathrm{A}}$ \\
& 6 & $2.90 \pm 0.85^{\mathrm{a}, \mathrm{A}}$ & $2.75 \pm 0.79^{\mathrm{a}, \mathrm{A}}$ & $4.25 \pm 1.12^{\mathrm{b}, \mathrm{A}}$ \\
& 9 & $2.90 \pm 0.85^{\mathrm{a}, \mathrm{A}}$ & $3.20 \pm 0.83^{\mathrm{a}, \mathrm{A}}$ & $4.25 \pm 0.97^{\mathrm{b}, \mathrm{A}}$ \\
& 12 & $2.95 \pm 0.69^{\mathrm{a}, \mathrm{A}}$ & $3.10 \pm 0.72^{\mathrm{a}, \mathrm{A}}$ & $3.85 \pm 0.99^{\mathrm{b}, \mathrm{A}}$ \\
& 0 & $2.30 \pm 0.66^{\mathrm{a}, \mathrm{A}}$ & $2.30 \pm 0.57^{\mathrm{a}, \mathrm{A}}$ & $2.10 \pm 0.55^{\mathrm{a}, \mathrm{A}}$ \\
& 3 & $2.35 \pm 0.49^{\mathrm{a}, \mathrm{A}}$ & $2.40 \pm 0.50^{\mathrm{a}, \mathrm{A}}$ & $2.25 \pm 0.55^{\mathrm{a}, \mathrm{A}}$ \\
& 6 & $2.20 \pm 0.62^{\mathrm{a}, \mathrm{A}}$ & $2.30 \pm 0.57^{\mathrm{a}, \mathrm{A}}$ & $2.10 \pm 0.55^{\mathrm{a}, \mathrm{A}}$ \\
& 9 & $2.35 \pm 0.67^{\mathrm{a}, \mathrm{A}}$ & $2.50 \pm 0.61^{\mathrm{a}, \mathrm{A}}$ & $2.10 \pm 0.55^{\mathrm{a}, \mathrm{A}}$ \\
& 12 & $2.15 \pm 0.59^{\mathrm{a}, \mathrm{A}}$ & $2.30 \pm 0.47^{\mathrm{a}, \mathrm{A}}$ & $1.95 \pm 0.60^{\mathrm{a}, \mathrm{A}}$ \\
\hline
\end{tabular}

${ }^{\mathrm{a}-\mathrm{b}}$ Means within a row with different superscripts differ $(P<0.05)$.

${ }^{\mathrm{A}}$ Means within a column for a given item with different superscripts differ $(P<0.05)$.

${ }^{1} \mathrm{~A}$ unipolar scale ranging from 1 to 9 was used. For caking and flowability, $1=$ none/absent and $9=$ highest intensity; for color, $1=$ white and $9=$ brownish cream.

${ }^{2} \mathrm{CON}=$ control cheese powder, $\mathrm{WACP}=$ whey-added cheese powder, $\mathrm{MACP}=$ maltodextrin-added cheese powder.

whereas MACP was described as "between slightly and moderately flowable" by panelists. In the current study, we found that fat content (especially free fat content) and particle geometry contributed to significant effects on flowability of dairy powders. Decrease in free fat content and increase in sphericity of powder particles increases flowability (Kim et al., 2002; Foster et al., 2005; Paterson et al., 2007). Although this study focused on the physical properties of cheese powders, one of the most important features was the cheese flavor intensity of the powders. Panelists did not determine a significant difference in cheese flavor intensity of powders during storage, although CON and WACP samples were described in the same group and defined as having "significant cheese flavor" with sensory analysis scores of 7.20 and 6.95 points, respectively. The MACP samples were noted to have as "medium cheese flavor" with 5.70 points after 12 mo of storage.

\section{CONCLUSIONS}

We produced white cheese powders with addition of whey and maltodextrin, stored them for $12 \mathrm{mo}$, and investigated changes in physical quality parameters due to formulation and during storage. Addition of maltodextrin significantly improved the physical properties of cheese powders, yielding powders with high densities, good reconstitution properties, and low free fat contents. The MACP particles were large, spherical, and uniform, whereas $\mathrm{CON}$ and WACP particles were shrunken, irregularly shaped with deep surface dents, and of variable size. Caking resulted from the free fat contents of CON and WACP at the end of 12 mo of storage, as noted on scanning electron micrographs. Moreover, we detected a significant decrease in $a$ values and increase in $b$ values (i.e., browning) for all cheese powder samples during storage. The physical properties of cheese powders can be improved and use of ripened cheese can be reduced by addition of maltodextrin into cheese powder formulations. Additionally, use of ripened cheese during cheese powder production was decreased by $13 \%$ when using whey in the powder formulation.

\section{ACKNOWLEDGMENTS}

This study is a part of the $\mathrm{PhD}$ thesis of Z. Erbay titled "Optimization of Spray Drying and Determination of Effects of Using Whey and Maltodextrin during White Cheese Production on Product Quality and Storage Stability." The authors are grateful for the financial support provided for the project (no. 2012/MÜH/020) by Ege University Scientific Research Project (Izmir, Turkey); Sütaş Dairy Company (Bursa, Turkey) for providing cheese; Yildiz Group (Istanbul, Turkey) for providing atomizer; and Kipa Chemical Company (Istanbul, Turkey) for providing emulsifying salt.

\section{REFERENCES}

AOAC International. 2000a. Nitrogen (total) in milk; Official Method 991.20. Official Methods of Analysis. 17th ed. AOAC International, Gaithersburg, MD. 
AOAC International. 2000b. Ash of dried milk, Official Method 930.30. Official Methods of Analysis. 17th ed. AOAC International, Gaithersburg, MD.

AOAC International. 2000c. Titratable acidity in milk product. Official Method 947.05. Official Methods of Analysis. 17th ed. AOAC International, Gaithersburg, MD.

Askari, G. R., Z. Emam-Djomeh, and S. M. Mousavi. 2008. Investigation of microwave treatment on the optical properties of apple slices during drying. Dry. Technol. 26:1362-1368.

Barbosa-Canovas, G. V., and P. Juliano. 2007. Desorption phenomena in food dehydration processes. Pages 313-340 in Water Activity in Foods: Fundamentals and Applications. G. V. Barbosa-Canovas, A. J. Fontana Jr., S. J. Schmidt, and T. P. Labuza, ed. Blackwell Publishing, Oxford, UK.

Barbosa-Canovas, G. V., E. Ortega-Rivas, P. Juliano, and H. Yan. 2005. Food Powders: Physical Properties, Processing, and Functionality. Kluwer Academic Publishers, New York, NY.

Bell, L. N. 2007. Moisture effect on food's chemical stability. Pages 173-198 in Water Activity in Foods: Fundamentals and Applications. G. V. Barbosa-Canovas, A. J. Fontana Jr., S. J. Schmidt, and T. P. Labuza, ed. Blackwell Publishing, Oxford, UK.

Charve, J., and G. A. Reineccius. 2009. Encapsulation performance of proteins and traditional materials for spray dried flavors. J. Agric. Food Chem. 57:2486-2492.

Chronakis, I. S. 1998. On the molecular characteristics, compositional properties, and structural-functional mechanisms of maltodextrins: A review. Crit. Rev. Food Sci. Nutr. 38:599-637.

Cunha, C. R., and W. H. Viotto. 2010. Casein peptization, functional properties, and sensory acceptance of processed cheese spreads made with different emulsifying salts. J. Food Sci. 75:C113-C120.

Danviriyakul, S., D. J. McClements, E. Decker, W. W. Nawar, and P. Chinachotti. 2002. Physical stability of spray-dried milk fat emulsion as affected by emulsifiers and processing conditions. J. Food Sci. 67:2183-2189.

Das, A., and R. B. Sharma. 2009. The effect of fluid goat milk whey on some quality characteristics of chevon nuggests. Ital. J. Food Sci. 21:81-88.

Dissanayake, M., S. Liyanaarachchi, and T. Vasiljevic. 2012. Functional properties of whey proteins microparticulated at low $\mathrm{pH}$. J. Dairy Sci. 95:1667-1679.

Erbay, Z., and N. Koca. 2012a. Investigating the effects of operating conditions on the exergetic performance of a pilot-scale spray-drying system. Biosyst. Eng. 11:302-321.

Erbay, Z., and N. Koca. 2012b. Energetic, exergetic and exergoeconomic analyses of spray drying process during white cheese powder production. Dry. Technol. 30:435-444.

Erbay, Z., and N. Koca. 2014. Exergoeconomic performance assessment of a pilot-scale spray dryer using the specific exergy costing method. Biosystems Eng. 122:127-138.

Erbay, Z., N. Koca, F. Kaymak-Ertekin, and M. Ucuncu. 2015. Optimization of spray drying process in cheese powder production. Food Bioprod. Proc. 93:156-165.

Fitzpatrick, J. J., K. Barry, P. S. Cerqueira, T. Iqbal, J. O'Neill, and Y. H. Roos. 2007. Effect of composition and storage conditions on the flowability of dairy powders. Int. Dairy J. 17:383-392.

Fitzpatrick, J. J., T. Iqbal, C. Delaney, T. Twomey, and M. K. Keogh. 2004. Effect of powder properties and storage conditions on the flowability of milk powders with different fat contents. Int. J. Food Eng. 64:435-444.

Foster, K. D., J. E. Bronlund, and A. H. J. T. Paterson. 2005. The contribution of milk fat towards the caking of dairy powders. Int. Dairy J. 15:85-91.

Freudig, B., S. Hogekamp, and H. Schubert. 1999. Dispersion of powders in liquids in a stirred vessel. Chem. Eng. Process. 38:525-532.

Gaiani, C., J. J. Ehrhardt, J. Scher, J. Hardy, D. Desobry, and S. Banon. 2006. Surface composition of dairy powders observed by $\mathrm{X}$-ray photoelectron spectroscopy and effects on their rehydration properties. Colloids Surf. B Biointerfaces 49:71-78.

GEA Niro. 2005a. A/S Niro Atomizer: Determination of wettability. GEA Niro Method No. A5a. Accessed Apr. 3, 2015. http://www. niro.com/NIRO/CMSDoc.nsf/WebDoc/ndkw6u9bbd.
GEA Niro. 2005b. A/S Niro Atomizer: Determination of surface free fat of powder. GEA Niro Method No. A10a. Accessed Apr. 3, 2015. http://www.niro.com/NIRO/CMSDoc.nsf/webdoc/ndkw6u9c45.

Gianfrancesco, A., C. Turchiuli, D. Flick, and E. Dumoulin. 2010. CFD modeling and simulation of maltodextrin solutions spray drying to control stickiness. Food Bioprocess Technol. 3:946-955.

Goula, A. M., and K. G. Adamopoulos. 2008. Effect of maltodextrin addition during spray drying of tomato pulp in dehumidified air: I. Drying kinetics and product recovery. Dry. Technol. 26:714-725.

Guinee, T. P. 2011. Cheese as a food ingredient. Pages 822-833 in Encyclopedia of Dairy Sciences. 2nd ed. Vol. 1. J. W. Fuquay, P. F. Fox and P. L. H. McSweeney, ed. Elsevier/Academic Press, London, UK.

Hawthorne, J. R. 1944. Methods for determination of solubility of dried whole egg. J. Soc. Chem. Ind. 63:6-8.

Hoppe, C., G. S. Andersen, S. Jaconsen, C. Molgaard, H. Friis, P. T. Sangild, and K. F. Michaelsen. 2008. The use of whey or skimmed milk powder in fortified blended foods for vulnerable groups. J. Nutr. 138:145S-161S

IDF. 1981. Milk-Determination of fat content: Gerber Butyrometers. IDF Standard 105. International Dairy Federation (IDF), Brussels, Belgium.

IDF. 1982. Determination of the total solid content (cheese and processed cheese). IDF Standard 4A. International Dairy Federation (IDF), Brussels, Belgium.

IDF. 1988. Determination of salt content (Mohr method). IDF Standard 12B. International Dairy Federation (IDF), Brussels, Belgium.

Jinapong, N., M. Suphantharika, and P. Jamnong. 2008. Production of instant soymilk powders by ultrafiltration, spray drying and fluidized bed agglomeration. J. Food Eng. 84:194-205.

Jouppila, K., and Y. H. Roos. 1994. Glass transition and crystallization in milk powders. J. Dairy Sci. 77:2907-2915.

Kelly, J., P. M. Kelly, and D. Harrington. 2002. Influence of processing variables on the physicochemical properties of spray dried fatbased milk powders. Dairy Sci. Technol. 82:401-412.

Kelly, P. M. 2006. Innovation in milk powder technology. Int. J. Dairy Technol. 59:70-75.

Keogh, K., M. Twomey, B. O'Kennedy, and D. Mulvihill. 2002. Effect of milk composition on spray-dried high-fat milk powders and their use in chocolate. Lait 82:531-539.

Kim, E. H. J., X. D. Chen, and D. Pearce. 2002. Surface characterization of four industrial spray-dried dairy powders in relation to chemical composition, structure and wetting property. Colloids Surf. B Biointerfaces 26:197-212.

Kim, E. H. J., X. D. Chen, and D. Pearce. 2009. Surface composition of industrial spray-dried milk powders. 1. Development of surface composition during manufacture. J. Food Eng. 94:163-168.

Koca, N., Z. Erbay, and F. Kaymak-Ertekin. 2015. Effects of spraydrying conditions on the chemical, physical, and sensory properties of cheese powder. J. Dairy Sci. 98:2934-2943.

Labuza, T. P., and B. Altunakar. 2007. Water activity prediction and moisture sorption isotherms. Pages 109-154 in Water Activity in Foods: Fundamentals and Applications. G. V. Barbosa-Canovas, A. J. Fontana Jr., S. J. Schmidt, and T. P. Labuza, ed. Blackwell Publishing, Oxford, UK

Martins, P. C., and T. G. Kieckbusch. 2008. Influence of a lipid phase on steam jet agglomeration of maltodextrin powders. Powder Technol. 185:258-266.

Martins, P. C., and T. G. Kieckbusch. 2010. Influence of a lipid phase on the physical properties of spray-dried maltodextrin powders. Chem. Eng. Technol. 33:292-298.

Papadakis, S. E., C. Gardeli, and C. Tzia. 2006. Spray drying of raisin juice concentrate. Dry. Technol. 24:173-180.

Park, C. W., E. Bastian, B. Farkas, and M. A. Drake. 2014. The effect of feed solids concentration and inlet temperature on the flavor of spray-dried whey protein concentrate. J. Food Sci. 79:C19-C24.

Park, C. W., and M. A. Drake. 2014. The distribution of fat in dried dairy particles determines flavor release and flavor stability. J. Food Sci. 79:R452-R459. 
Paterson, A. H., J. Z. Zuo, J. E. Bronlund, and R. Chatterjee. 2007. Stickiness curves of high fat dairy powders using the particle gun. Int. Dairy J. 17:998-1005.

Richard, B., J. F. Le Page, P. Schuck, C. Andre, R. Jeantet, and G. Delaplace. 2013. Towards a better control of dairy powder rehydration processes. Int. Dairy J. 31:18-28.

Schuck, P. 2007. Why a bibliographic review on free fat in dairy powders? Lait 87:183-185.

Schuck, P. 2011. Milk powder: Physical and functional properties of milk powders. Pages 117-124 in Encyclopedia of Dairy Sciences. 2nd ed. Vol. 2. J. W. Fuquay, P. F. Fox and P. L. H. McSweeney, ed. Elsevier/Academic Press, London, UK.

Schuck, P., S. Mejean, A. Dolivet, R. Jeantet, and B. Bhandari. 2007. Keeping quality of dairy ingredients. Lait 87:481-488.

Stapelfeldt, H., B. R. Nielsen, and L. H. Skibsted. 1997. Effect of heat treatment, water activity and storage temperature on the oxidative stability of whole milk powder. Int. Dairy J. 7:331-339.

Svarovsky, L. 1987. Powder Testing Guide: Methods of Measuring the Physical Properties of Bulk Powders. Elsevier Applied Science, New York, NY.

Terra, N. N., L. L. M. Fries, L. I. G. Milani, N. S. P. D. Richards, A. P. D. Rezer, A. M. Backes, S. Beulch, and B. A. dos Santos. 2009 Employment of fluid whey in the elaboration of mortadela. Cienca Rural 39:885-890.
Thomas, M. E. C., J. Scher, S. Desobry-Banon, and S. Desobry. 2004 Milk powders ageing: Effect on physical and functional properties. Crit. Rev. Food Sci. Nutr. 44:297-322.

Vignolles, M. L., R. Jeantet, C. Lopez, and P. Schuck. 2007. Free fat, surface fat and dairy powders: interactions between process and product-A review. Dairy Sci. Technol. 87:187-236.

Vignolles, M. L., C. Lopez, M. N. Madec, J. J. Ehrhardt, S. Mejean, P. Schuck, and R. Jeantet. 2009. Fat properties during homogenization, spray-drying, and storage affect the physical properties of dairy powders. J. Dairy Sci. 92:58-70

West, S. 2007. Production of flavours, flavour enhancers and other protein-based speciality products. Pages $183-214$ in Novel Enzyme Technology for Food Applications. R. Rastall, ed. CRC Press, Boca Raton, FL.

Yetim, H., W. D. Müller, M. Doğan, and P. G. Klettner. 2006. Using fluid whey in comminuted meat products: Effects on textural properties of frankfurter-type sausages. J. Muscle Foods 17:354-366.

Yetim, H., W. D. Müller, and M. Eber. 2001. Using fluid whey in comminuted meat products: Effects on technological, chemical and sensory properties of frankfurter-type sausages. Food Res. Int $34: 97-101$ 